\title{
IMPLEMENTASI PERADILAN ELEKTRONIK (E-COURT) PASCA DIUNDANGKANNYA PERMA NOMOR 3 TAHUN 2018 TENTANG ADMINISTRASI PERKARA DI PENGADILAN SECARA ELEKTRONIK
}

\author{
Hary Djatmiko \\ (Hakim di Mahkamah Agung RI) \\ e-mail:Hari96@gmail.com
}

\begin{abstract}
The continuous development of information and technology (IT), demands its adoption in court institutions worldwide. Therefore, the application of e-court in Indonesia started after the publication of Supreme Court Regulation number 3 of 2018. The purpose of this article is to describe the adaptation of the Indonesian Supreme Court to the use of information technology, in an effort to improve its performance. This research focuses on two research problems, firstly, how is the regulation and implementation of electronic court in Indonesia? Secondly, what are the implications of accessing its application among justice seekers? A normative approach, which relates the broad access towards the justice seeker, was used. The implementation of IT in court processes is a reformative initiative, through innovation, efficiency, structure and system. This advancement would also assist the judges in examining, judging and declaring a case. Socially, these further helps those who seek justice to cost effectively simplify and hasten the process, therefore mark a new era.
\end{abstract}

Keywords: Information technology, e-court, access to justice

Abstrak: Laju perkembangan teknologi informasi pada akhirnya menuntut badan-badan peradilan di berbagai negara tak terkecuali di Indonesia untuk mulai mengadopsi penggunaan teknologi informasi. Penerapan e-court di Indonesia telah mulai diterapkan paska keluarnya Peraturan Mahkamah Agung Nomor 3 Tahun 2018. Tujuan penulisan artikel ini adalah untuk mendeskripsikan adaptasi Mahkamah Agung terkait penggunaan teknologi nformasi sebagai upaya meningkatkan kinerjanya. Artikel ini mengajukan dua permasalahan yakni Pertama, Bagaimanakah pengaturan dan implementasi peradilan elektronik di Indonesia? Kedua, Bagaimanakah implikasi penerapan $e_{-}$ court dalam kaitannya terhadap akses terhadap keadilan bagi para pencari keadilan? Pendekatan normatif digunakan dalam menganalisis penerapan $e$-court dan kaitannya terhadap perluasan akses terhadap keadilan bagi para pencari keadilan. Kesimpulan artikel ini adalah bahwa penerapan teknologi informasi dalam peradilan di Indonesia meruoakan sebuah usaha Mahkamah Agung untuk melakukan reformasi peradilan melalui peningkatan dan inovasi, efisiensim struktur dan sistem. Penggunaan teknologi informasi juga membantu hakim dalam memeriksa, memutusa dan mengadili seuatu perkara. Implikasi sosial penerapan e-court bagi para pencari keadilan melalui penerapan e-court bagi para pencari keadilan di pengadilan adalah semakin sederhana,cepat dan yang terpenting juga adalah berbiaya ringan. Dengan demikian penerapan ecourt menjadi penanda era baru pengadilan modern di Indonesia.

Kata Kunci : teknologi informasi, e-court, akses terhadap keadilan 


\section{A. Pendahuluan.}

Dalam era dunia Gelombang Ketiga sebagaimana dinyatakan oleh Alfin Toffler, perkembangan masyarakat saat ini telah memasuki, dalam istilah Rhenald Kasali, Model Peradaban Uber. ${ }^{1}$ Model Peradaban Uber ini dicirikan dengan perubahan peradaban time series menjadi real time, sikap individualis berubah menjadi saling berkolaborasi/berjejaring, kecepatan, multitasking, dan adanya kompetitor yang tidak terlihat.2Perkembangan Teknologi Informasi yang sangat cepat tersebut juga merambah ke dunia hukum, karena pada dasarnya "hukum adalah masyarakat itu juga", sehingga hubungan-hubungan masyarakat baru akan membentuk peraturan-peraturan baru. ${ }^{3}$

Laju perkembangan teknologi informasi dalam Peradaban Uber ini tentu berpengaruh pada Mahkamah Agung.Jika sebelumnya pengadministrasian perkara dilaksanakan secara manual yang memakan waktu lama dan biaya tinggi, teknologi informasi telah mempercepat, mempermudah dan mempermurah biaya pengadministrasian perkara di lingkungan Mahkamah Agung.

Ide pemanfaatan teknologi informasi untuk tugas-tugas peradilan tersebut saat ini semakin berkembang pesat menuju Peradilan Elektronik (ecourt), dimana teknologi informasi didayagunakan dalam pengadministrasian perkara dan pelaksanaan hukum acara. Sebagai perbandingan, di Australia sudah ada online dispute resolution (Penyelesaian Sengketa secara online) ${ }^{4}$, dimana pihak berperkara dapat menyelesaikan sengketanya secara online.Di Amerika Serikat juga, sejak tahun 1999 telah dimulai Public Access to Electronic Record (PACER), juga ada sistem Case Management and Electronic Case Files (CM/ECF), dan berbagai pemanfaatan teknologi informasi untuk menunjang tugas peradilan. ${ }^{5}$

\footnotetext{
${ }^{1}$ Rhenald Kasali, Disruption (Jakarta, PT Gramedia Pustaka Utama, 2017), hlm. 21.

${ }^{2}$ Ibid, hlm. 21-23;

${ }^{3}$ Van Apeldoorn, Pengantar Ilmu Hukum, (Jakarta: Pradnya Paramita, 1986), hlm. 18.

${ }^{4}$ WebsiteDirektoratJenderalBadan Peradilan Agama.https://badilag.mahkamahagung.go.id/seputar -ditjen-badilag/di-family-court-of-australia-ini-yang-dipelajari-para-inovator-pengadilan;

${ }^{5}$ http://www.uscourts.gov/courtrecords/find-case-pacer dan http://www.uscourts.gov/courtrecords/electrnic-filling-cmecf;
} 
Penerapan Peradilan Elektronik sangat membantu terwujudnya Visi Mahkamah Agung menjadi Badan Peadilan Indonesia Yang Agung, yang pada point ke-10 perwujudan Visi Mahkamah Agung dalam Cetak Biru Pembaruan Peradilan 2010-2035 adalah mewujudkan Badan Peradilan Modern dengan berbasis Tekonologi Informasi Terpadu. Dalam upaya mewujudkan Visi Mahkamah Agung tersebut, telah dinyatakan adanya Modernisasi Manajemen Perkara, mulai dari Pelaporan Perkara Berbasis Elektronik hingga Pengadilan online.

Kemajuan Teknologi Informasi yang sedemikian cepat dan telah mempermudah kerja manusia (termasuk tugas peradilan) bukan tanpa efek samping yang berdampak buruk bagi manusia/masyarakat/Negara. Informasi yang tidak terkontrol akan berdampak pada chaos of information pollution, yang memberikan data-data yang tidak bernilai guna. ${ }^{6}$ Informasi yang tidak terseleksi tersebut akhirnya menjadi information overload, yang berujung pada information gult (informasi yang menyesatkan), yang sangat berbahaya bagi manusia/masyarakat/negara. ${ }^{7}$

Pemerintah bersama-sama dengan DPR berupaya untuk mencegah dampak buruk dari semakin berkembangnya teknologi informasi telah mengeluarkan Undang-Undang Nomor 11 Tahun 2008 sebagaimana telah diubah dengan Undang-Undang Nomor 19 Tahun 2016 tentang Perubahan Atas Undang-Undang Nomor 11 Tahun 2008 tentang Informasi dan Transaksi Elektronik.

Dalam kaitannya dengan pemanfaatan Teknologi Informasi, Mahkamah Agung dan Pengadilan di bawahnya telah menggunakan Teknologi Informasi guna membantu kinerja peradilan.Ada puluhan Sistem Informasi yang menunjang tugas peradilan tersebut menunjukan kualitas sumber daya manusia Mahkamah Agung di bidang Teknologi Informasi yang sangat bagus dan harus diapresiasi positif.Adapun sistem informasi yang dimaksud adalah Sistem Informasi Mahkamah Agung (SIMARI). Selanjutnya untuk memberikan legalitas bagi aparatur peradilan dan juga masyarakat pencari keadilan dalam

\footnotetext{
${ }^{6}$ John Naisbit, dalam Nina Winangsih Syah, Komunikasi Peradaban (Bandung: PT Remaja Rosdakarya, 2014), hlm 56.

${ }^{7}$ Helen Rothschild Ewald dan Rebecca E. Burnett, dalam Nina Winangsih Syah, Ibid. hlm 61.
} 
penggunaan Teknologi Informasi di Peradilan, Mahkamah Agung telah menerbitkan Peraturan Mahkamah Agung Nomor 3 Tahun 2018 tentang Administrasi Perkara Di Pengadilan Secara Elektronik.

Perkembangan peradilan-peradilan di dunia juga mulai mengarah pada pembangunan integrated judiciary (i-Judiciary), dan tidak lagi sebatas e-Court. Artinya, para pengguna manfaat teknologi peradilan tidak hanya terfokus pada pihak yang menjadi pemohon agar mengajukan permohonan dengan cara online, namun juga melibatkan seluruh pihak dan lembaga-lembaga terkait lainnya yang berperkara.

Berdasarkan hal tersebut di atas, perlu dilakukan kajian Implementasi Peradilan Elektronik (e-court) Pasca Diundangkannya Perma Nomor 3 Tahun 2018 tentang Administrasi Perkara Di Pengadilan Secara Elektronik. Kajian ini diperlukan untuk mengetahui efektivitas penyelenggaraan Administrasi Perkara secara elektronik di Mahkamah Agung dan Peradilan dibawahnya.

\section{B. Permasalahan}

Permasalahan dalam makalah ini adalah :

1. Bagaimanakah penyelenggaraan Administrasi Perkara secara elektronik di Pengadilan pasca diundangkannya Perma Nomor 3 Tahun 2018?

2. Apakah implikasi bagi para pencari keadilan terhadap akses ke keadilan (access to justice) di Pengadilan pasca diundangkannya Perma Nomor 3 Tahun 2018?

\section{Metode}

Penulisan artikel ini menggunakan pendekatan normatif dalam menganalisis penerapan e-court secara kualitatif dalam melihat perluasan akses terhadap keadilan bagi para pencari keadilan paska keluarnya Perma Nomor 3 Tahun 2018. 


\section{Pembahasan}

1. Penyelenggaran Administrasi Perkara secara Elektronik di Pengadilan Pasca Diundangkannya Perma Nomor 3 Tahun 2018

Pengaturan atas Tata Kelola Teknologi Informasi pada penyelenggaraan Negara (termasuk Mahkamah Agung) diatur dalam Undang-Undang Nomor 11 Tahun 2008 tentang Informasi dan Transaksi Elektronik sebagaimana telah diubah dengan Undang-Undang Nomor 19 Tahun 2016 tentang Perubahan atas Undang-Undang Nomor 11 Tahun 2008 tentang Informasi dan Transaksi Elektronik (selanjutnya disebut juga UU ITE). Pasal 1 angka 3 UU ITE mendefinisikan Teknologi Informasi sebagai "suatu teknik untuk mengumpulkan, menyiapkan, menyimpan, memproses, mengumumkan, menganalisis, dan/atau menyebarkan informasi".

Di dalam melaksanakan pelayanan publik, penyelenggara Negara dapat menyelenggarakan Sistem Elektronik dengan memanfaatkan Teknologi Informasi dan bertanggung jawab atas Penyelenggaraan Sistem Elektronik tersebut. ${ }^{8}$ Pasal 1 angka 32 Peraturan Pemerintah Nomor 82 Tahun 2012 tentang Penyelenggaraan Sistem dan Transaksi Elektronik merinci Instansi Penyelenggara Negara terdiri atas institusi legislatif, eksekutif, dan yudikatif di tingkat pusat dan daerah dan instansi lain yang dibentuk dengan peraturan perundang-undangan.

Kemudian yang dimaksud dengan Sistem Elektronik adalah serangkaian perangkat dan prosedur elektronik yang berfungsi mempersiapkan, mengumpulkan, mengolah, menganalisis, menyimpan, menampilkan, mengumumkan, mengirimkan, dan/atau menyebarkan Informasi Elektornik. ${ }^{9}$ Untuk menjaga standar Sistem Elektronik yang digunakan oleh penyelenggara Negara sehingga tidak mengakibatkan kerugian kepada publik atau penyelenggara Negara lainnya, telah ditentukan standar minimum Sistem Elektronik tersebut, yaitu:

${ }^{8}$ Pasal 1 angka 6 juncto Pasal 15 ayat (1) dan ayat (2) UU ITE.

${ }^{9}$ Pasal 1 angka 5 UU ITE. 
a. Dapat menampilkan kembali Informasi Elektronik dan/atau Dokumen Elektronik secara utuh sesuai dengan masa retensi yang ditetapkan dengan peraturan perundang-undangan.

b. Dapat melindungi ketersediaan, keutuhan, keontentikan, kerahasiaan, dan keteraksesan Informasi Elektronik dengan Penyelenggaraan Sistem Elektronik tersebut.

c. Dapat beroperasi sesuai dengan prosedur atau petunjuk dalam penyelenggaraan Sistem Elektronik tersebut.

d. Dilengkapi dengan prosedur atau petunjuk yang diumumkan dengan bahasa, informasi, atau simbol yang dapat dipahami oleh pihak yang bersangkutan dengan Penyelenggaraan Sistem Elektronik tersebut; dan

e. Memiliki mekanisme yang berkelanjutan untuk menjaga kebaruan, kejelasan, dan kebertanggungjawaban prosedur atau petunjuk

Kedudukan Sistem Elektronik sangat penting bagi dunia peradilan, karena Informasi Elektronik dan/atau Dokumen Elektronik dan/atau hasil cetaknya merupakan alat bukti hukum yang sah, yang merupakan perluasan dari alat bukti yang sah dalam Hukum Acara yang berlaku di Indonesia, dengan syarat Informasi Elektronik dan/atau Dokumen Elektronik tersebut menggunakan sistem elektronik sesuai dengan ketentuan yang diatur dalam UU ITE.10

Bentuk perlindungan hukum bagi publik atas penyelenggaraan pelayanan publik melalui Sistem Elektronik tersebut, Pasal 5 Peraturan Pemerintah Nomor 82 Tahun 2012 telah menegaskan bahwa Penyelenggara Sistem Elektronik untuk pelayanan publik wajib melakukan pendaftaran kepada Menteri Komunikasi dan Informatika sebelum sistem elektonik tersebut digunakan. Menindaklanjuti Pasal 5 Peraturan Pemerintah Nomor 82 Tahun 2012 tersebut, Menteri Komunikasi dan Informatika telah menerbitkan Peraturan Menteri Komunikasi dan Informatika Nomor 10 Tahun 2015 tentang Tata Cara Pendaftaran Sistem Elektronik Instansi Penyelenggara Negara, mulai dari persyaratan-persyaratan, pejabat pendaftarnya, prosedurnya, pengesahan hingga formulir/template yang digunakan.

${ }^{10}$ Pasal 5 ayat (1), ayat (2) dan ayat (3) UU ITE. 
Cetak biru pembaharuan peradilan 2010-2035 telah menetapkan bahwa salah satu peradilan yang ideal adalah Peradilan yang modern dengan berbasis Teknologi Informasi terpadu.Adanya kata Terpadu muncul dari permasalahan bahwa saat penyusunan cetak biru tersebut, yakni di sekitar sebelum tahun 2010, Mahkamah Agung telah menyadari bahwa belum terdapat manajemen teknologi informasi yang komprehensif dan terintegrasi.11Dalam rangka menjawab persoalan tersebut di atas, maka ditetapkan arahan pembaruan teknologi informasi. ${ }^{12}$ Arahan pembaruan tersebut idealnya menjadi dasar utama penyusunan regulasi tata kelola Teknologi Informasi yang menyeluruh yakni mengatur mengenai penggunaan dan pemanfaatan Teknologi Informasi dari hulu hingga ke hilir.

Sebelum diundangkannya Perma Nomor 3 Tahun 2018 tentang Administrasi Perkara Di Pengadilan Secara Elektronik, Mahkamah Agung telah membuat aturan yang berhubungan dengan penggunaan Teknologi Informasi, antara lain:

1. Keputusan Ketua Mahkamah Agung Nomor 1-144/KMA/SK/1/2011 tentang Pedoman Pelayanan Informasi di Pengadilan.

2. Pedoman Rancangan dan Prinsip Aksessibilitas Website Pengadilan di Lingkungan Mahkamah Agung.

3. Surat Edaran Mahkamah Agung RI Nomor 14 Tahun 2010 tentang Dokumen Elektronik sebagai Kelengkapan Permohonan Kasasi dan Peninjauan Kembali sebagaimana telah diubah dengan Surat Edaran Mahkamah Agung RI Nomor 1 Tahun 2014 tentang Perubahan atas Surat Edaran Mahkamah Agung RI Nomor 14 Tahun 2010 tentang Dokumen Elektronik sebagai Kelengkapan Permohonan Kasasi dan Peninjauan Kembali.

4. Surat Edaran Direktur Jenderal Badan Peradilan Umum Nomor 3 /Dju/Hm.02.3/6/2014 tentang Administrasi Pengadilan Berbasis Teknologi Informasi di Lingkungan Peradilan Umum.

5. Peraturan Mahkamah Agung Republik Indonesia Nomor 9 Tahun 2016 tentang Pedoman Penanganan Pengaduan (Whistleblowing System) di

${ }^{11}$ Cetak Biru Pembaharuan Peradilan 2010-2035, Bab II Hlm. 7.

${ }^{12}$ Ibid, Bab V Hlm. 63. 
Mahkamah Agung dan Badan Peradilan yang Berada Di Bawahnya, dalam peraturan ini terdapat pengaturan mengenai aplikasi Sistem Informasi Pengawasan (Siwas).

6. Keputusan Direktur Jenderal Badan Peradilan Agama Mahkamah Agung Republik Indonesia Nomor 2273.A/Kp.01.1/SK/VII/2014 tentang Petunjuk Teknis Pelaksanaan dan Pemanfaatan Portal Tabayun di Lingkungan Badan Peradilan Agama Mahkamah Agung Republik Indonesia.

7. Surat Edaran Direktur Jenderal Badan Peradilan Militer dan Peradilan Tata Usaha Negara Nomor 1532/Djmt/B/12/2012 tanggal 11 Desember 2012.

Pada tanggal 29 Maret 2018 lalu, Mahkamah Agung telah menerbitkan Perma Nomor 3 Tahun 2018 tentang Administrasi Perkara di Pengadilan secara Elektronik, melalui Perma Nomor 3 Tahun 2018 tersebut, Mahkamah Agung melakukan serangkaian inovasi dan pembaharuan sistem peradilannya. Setidaknya ada empat hal yang tercermin dari pembaharuan tersebut.Pertama, para advokat yang akan berperkara harus sudah terdaftar datanya dalam sistem pendataan elektronik. Kedua, pendaftaran perkara mulai diarahkan secara elektronik (online), termasuk untuk pembayaran biaya perkaranya. Ketiga, panggilan bagi para pihak akan dikirimkan secara elektronik berdasarkan database yang didaftarkan. Keempat, Salinan putusan atau penetapan pengadilan juga akan dikirimkan secara elektronik kepada para pihak paling lambat 14 hari sejak putusan atau penetapan diucapkan.

Atas diterbitkannya Perma Nomor 3 Tahun 2018, Direktur Jenderal Badan Peradilan Militer dan Peradilan Tata Usaha Negara Mahkamah Agung RI telah menindaklanjutinya dengan mengeluarkan Surat Keputusan Direktur Jenderal Badan Peradilan Militer dan Peradilan Tata Usaha Negara Mahkamah Agung RI Nomor 307/Djmt/Kep/5/2018 tentang Petunjuk Pelaksanaan Peraturan Mahkamah Agung Nomor 3 Tahun 2018 tentang Administrasi Perkara di Pengadilan Secara Elektronik. 


\section{Implikasi Bagi Para Pencari Keadilan Terhadap Akses Ke Keadilan} (Access To Justice) Di Pengadilan Pasca Diundangkannya Perma Nomor 3 Tahun 2018.

Akses ke keadilan telah menjadi tema besar dalam agenda pembaruan peradilan yang lebih luas, seperti di dunia Barat dalam tahun 1970-an, sebuah gerakan dimulai dengan tujuan menyampaikan informasi tentang sejumlah hak untuk lebih dapat diakses oleh masyarakat umum, mendanai bantuan-bantuan hukum dan representasi legal menjadi sebuah fokus dari kebijakan pemerintah.Posisinya dalam agenda reformasi mengandung arti bahwa akses ke keadilan relevan sebagai sebuah topik dalam kerangka reformasi Peradilan.

Konvensi-konvensi Internasional menjamin akses ke pengadilan: Setiap orang berhak mendapatkan gelar perkara yang tidak berpihak dan terbuka oleh sebuah mahkamah yang independen dalam penentuan hak-hak serta kewajibankewajiban perdata mereka atau ketika mengalami dakwaan pidana yang dituduhkan kepada mereka. ${ }^{13}$

Hak untuk akses ini pada umumnya berhubungan dengan kesempatan yang sama untuk mendapatkan perlindungan hukum. Selain sistem peradilan yang berfungsi dengan baik harus memberikan kepada setiap orang kesempatan untuk melancarkan keberatan atas pelanggaran hak-hak mereka.

Informasi hukum yang dibuat untuk memberitahu masyarakat umum tentang hak-hak mereka, membantu mereka menyelesaikan perselisihan atau memberi tahu tentang bagaimana membawa suatu perkara ke pengadilan, penyelesaian secara damai di luar Pengadilan, oleh karenanya kemampuan menyebarluaskan informasi hukum dengan biaya melalui teknologi informasi khususnya internet, dipandang sebagai sebuah cara penting untuk meningkatkan akses ke keadilan.

Terdapat pepatah terkenal dalam kultur dunia peradilan adalah kutipan pidato Perdana Menteri Inggris William Gladstone, Justice delayed is justice denied yang padanan Perancisnya adalah adagium justice retive, justice fautive yang dapat diartikan bahwa keadilan yang tertunda merupakan bentuk ketidakadilan. Proses peradilan yang tepat waktu bukan sebuah hak yang bersifat abstrak,

\footnotetext{
${ }^{13}$ Dory Reiling, Teknologi Untuk Keadilan, (Bandung: PT. Alumni, 2018), hlm. 230
} 
selalu ada resiko bahwa keadilan dikhianati ketika proses perkaranya berlarutlarut.

Pasal 24 ayat (1) Undang-Undang Dasar Negara Kesatuan Indonesia Tahun 1945 menyebutkan bahwa tujuan penyelenggaraan peradilan adalah untuk menegakkan hukum dan keadilan. Selanjutnya Pasal 2 ayat (4) Undang-Undang Nomor 48 Tahun 2009 tentang Kekuasaan Kehakiman menyatakan bahwa Peradilan dilakukan dengan sederhana, cepat, dan biaya ringan. Dengan demikian arahan untuk melaksanakan penegakan hukum dan keadilan dengan sederhana, cepat dan biaya ringan ini harus menjadi pemandu bagi Peradilan Indonesia dalam melaksanakan tugas pokok dan fungsinya.

Dalam konteks penerapan administrasi perkara di Pengadilan secara elektronik sesuai dengan Perma Nomor 3 Tahun 2018 tersebut tidak akan bertentangan dengan Asas-Asas Umum Peradilan Yang Baik, justru sebaliknya sangat mendukung terwujudnya Asas-Asas Umum Peradilan Yang Baik dalam pelaksanaan tugas peradilan, misalnya Asas Peradilan Yang Terbuka Untuk Umum, dimana dengan penerapan administrasi perkara secara elektronik maka dokumen-dokumen tersebut tidak hanya dapat di akses oleh pihak-pihak yang berpekara, namun masyarakat umum dapat mengakses dan mengontrolnya juga. Dalam hal terkait Asas Kesempatan Untuk Membela Diri (audi et alteram partem), justru memberikan akses yang luas kepada Para Pihak untuk mengajukan pembelaannya sehingga lebih memberikan perlindungan bagi para pihak. Demikian juga dengan Asas Akuntabilitas, maka penerapan administrasi perkara secara elektronik akan meninggalkan jejak digital (digital footprint) yang tersimpan selamanya sehingga selain dapat dikontrol oleh publik juga dapat mencegah berkas hilang atau rusak.

\section{E. Simpulan}

Dari seluruh uraian pembahasan dalam makalah ini dapat disimpulkan, sebagai berikut.Setidaknya ada empat hal yang tercermin dari pembaharuan peradilan sebagaimana dimaksud dalam Perma Nomor 3 Tahun 2009 tentang Administrasi Perkara secara Elektronik di Pengadilan.Pertama, para advokat yang akan berperkara harus sudah terdaftar datanya dalam sistem pendataan elektronik. Kedua, pendaftaran perkara mulai diarahkan secara elektronik 
(online), termasuk untuk pembayaran biaya perkaranya. Ketiga, panggilan bagi para pihak akan dikirimkan secara elektronik berdasarkan database yang didaftarkan. Keempat, Salinan putusan atau penetapan pengadilan juga akan dikirimkan secara elektronik kepada para pihak paling lambat 14 hari sejak putusan atau penetapan diucapkan.

Penerapan Administrasi Perkara di Pengadilan secara Elektronik sebagaimana termuat dalam Perma Nomor 3 Tahun 2018 tersebut sangat mendukung tugas peradilan dalam menegakkan hukum dan keadilan yang senafas dengan asas Peradilan Sederhana, Cepat dan Biaya Ringan yang memberikan dampak positif bagi para pencari keadilan untuk mendapatkan akses ke keadilan (Access To Justice).

\section{Daftar Pustaka}

\section{Buku}

Dory Reiling, 2018, Teknologi Untuk Keadilan, PT. Alumni, Bandung.

Nina Winangsih Syah, 2014, Komunikasi Peradaban, PT Remaja Rosdakarya, Bandung.

Rhenald Kasali, 2017, Disruption, PT Gramedia Pustaka Utama, Jakarta.

Van Apeldoorn, 1986, Pengantar Ilmu Hukum, Pradnya Paramita, Jakarta.

\section{Website}

Tanpa Nama, "seputar -ditjen-badilag/di-family-court-of-australia-ini-yang-dipelajaripara-inovator-pengadilan", badilag.mahkamahagung.go.id, diakses 27 Juli 2019.

Tanpa Nama, "courtrecords find-case-pacer", uscourts.gov, diakses 27 juni2019.

Tanpa Nama, "courtrecords electrnic-filling-cmecf.", uscourts.gov, diakses 27 juni2019. 